\title{
The effects of baclofen and cholinergic drugs on upbeat and downbeat nystagmus
}

\author{
Marianne Dieterich, Andreas Straube, Thomas Brandt, Walter Paulus, Ulrich Büttner
}

\begin{abstract}
The GABAergic drug baclofen and the cholinergic drug physostigmine were administered to patients with upbeat and downbeat nystagmus. Baclofen (orally, $5 \mathrm{mg}$ three times daily) reduced nystagmus slow phase velocity and distressing oscillopsia by $25-75 \%$ in four out of five patients (two upbeat nystagmus; two downbeat nystagmus). Physostigmine (1 $\mathrm{mg}$ single intravenous injection) increased nystagmus in five additional patients with downbeat (1) or positional downbeat nystagmus (4) for a duration of 15-20 minutes. The different interactions of baclofen and physostigmine on neurotransmission subserving vertical vestibulo-ocular reflex could account for these effects. The response to baclofen appears to be a GABA-B-ergic effect with augmentation of the physiological inhibitory influence of the vestibulocerebellum on the vestibular nuclei. Similarly baclofen has an inhibitory effect on the velocity storage mechanism. Cholinergic action may cause the increment of nystagmus by physostigmine.
\end{abstract}

Upbeat and downbeat nystagmus in the primary position of gaze, with concomitant oscillopsia, reflect an imbalance of vertical vestibulo-ocular reflex tone in the pitch plane. ${ }^{1}$ Both are modulated by otolithic input. ${ }^{23}$ Alternatively, an imbalance of the vertical smooth pursuit system for downbeat nystagmus $^{4}$ has been proposed. However, features of the syndrome such as fore-aft postural instability ${ }^{2}$ cannot be explained with this hypothesis.

The pathways for upward- and downwardvestibulo-ocular reflexes (VOR), from the vestibular nuclei to the oculomotor nuclei, are partially separated. ${ }^{5}$ The vertical VOR is under the influence of the cerebellum, mainly the vestibulo-cerebellum which projects on to the vestibular nuclei. ${ }^{6}$ Upbeat nystagmus may be induced by disrupting the upward VOR pathways within the brachium conjunctivum ${ }^{7}$ or within structures of the caudal brainstem, such as perihypoglossal nuclei ${ }^{89}$ and the ventral tegmental pathway, ${ }^{10}$ which modulate VOR. The downbeat nystagmus syndrome, as demonstrated in monkeys, is caused by lesions of either the floor of the fourth ventricle between the vestibular nuclei ${ }^{11}$ or the flocculus. $^{1213}$
Little is known about neurotransmitters involved, although pathways for upward and downward VOR have been identified. Clinical evidence suggests cholinergic and gabaergic transmission. Cholinergic drugs (physostigmine) counteract a hyperactive horizontal VOR and disturbed fixation suppression of caloric nystagmus in familial ataxia ${ }^{14}$ and cerebellar degeneration. ${ }^{16}$ Anticholinergic drugs (scopolamine or trihexiphenidyl) suppress acquired pendular nystagmus and palatal myoclonus. ${ }^{17}$ The GABA-B-agonist baclofen effectively suppresses periodic and non-periodic alternating nystagmus. ${ }^{18-20}$

In this report, we describe the effects of baclofen (GABA-B-agonist) and physostigmine (cholinergic drug) in 10 patients with acquired upbeat (2), downbeat (4), or positional downbeat nystagmus (4). In one (patient 6), the effect of the anticholinergic drug biperiden, which was injected $10 \mathrm{~min}$ utes after physostigmine injection, was tested. It was found that baclofen inhibits upbeat and downbeat nystagmus in some patients and this has obvious clinical relevance. Physostigmine on the other hand, appeared to change the condition for the worse.

\section{Patients and methods}

Data for patients 1-10 are listed in table 1 .

Patients 7-10 showed slight downbeat nystagmus, with Frenzel's glasses, in the upright position of the head and positional downbeat nystagmus in the head hanging position. After physostigmine application (1 $\mathrm{mg}$ ), the increased downbeat nystagmus was recorded in the upright position with the eyes closed. There was no history of previous drug treatment in these patients.

Two healthy male subjects (aged 34 and 29 years respectively) were used as controls. Their eye movements were recorded with electro-oculography (EOG) before and after the intravenous injection of $1 \mathrm{mg}$ physostigmine.

Horizontal and vertical eye position was recorded separately by DC-EOG with a resolution of 1 degree. The linearity of DCEOG for recording vertical eye movements was \pm 30 degrees. The bandwidth of the recording system was $0-30 \mathrm{~Hz}$. EOG measurements of vertical eye movements contaminated by lid artifacts were dismissed. Eye movements and stimuli were stored on a six channel tape recorder and printed on a thermoprinter.

During recordings, the subject sat in a 
Table 1 Data for 10 patients

\begin{tabular}{|c|c|c|c|c|c|}
\hline $\begin{array}{l}\text { Patient } \\
\text { number }\end{array}$ & $\begin{array}{l}\text { Age/ } \\
\operatorname{sex}\end{array}$ & CNS signs/symptoms & Nystagmus & $M R I / C T / C S F$ & Aetiology \\
\hline 1 & $40 \mathrm{~F}$ & $\begin{array}{l}\text { For eight months: dysarthria, } \\
\text { dysphagia, numbness of the left } \\
\text { trigeminal nerve, gait-ataxia falling } \\
\text { to the right }\end{array}$ & Upbeat nystagmus syndrome & $\begin{array}{l}\text { Hypertensive metastasis in the } \\
\text { right ponto-medullary brainstem }\end{array}$ & $\begin{array}{l}\text { Adeno-papillary cancer of } \\
\text { the left hilum of the lung, } \\
\text { probably solitary metastasis; } \\
\text { no drugs before, no radio- } \\
\text { therapy }\end{array}$ \\
\hline 2 & $65 \mathrm{~F}$ & $\begin{array}{l}\text { For many years: oscillopsia and } \\
\text { slight ataxia, hyper-reflexia at the } \\
\text { right extremities, slight upward } \\
\text { gaze palsy }\end{array}$ & Downbeat nystagmus syndrome & $\begin{array}{l}\text { MRI, CSF: characteristic } \\
\text { abnormalities due to a multiple } \\
\text { sclerosis }\end{array}$ & Multiple sclerosis \\
\hline 3 & $79 \mathrm{~F}$ & $\begin{array}{l}\text { For five years: dizziness oscillopsia, } \\
\text { postural instability. Thirty year } \\
\text { history of hypertension, } \\
\text { dyslipidosis; mild anisocoria } \\
\text { (OS > OD) }\end{array}$ & Downbeat nystagmus syndrome & $\begin{array}{l}\text { CT, EEG, BAEP, CSF, Doppler } \\
\text { ultrasonography of the extracranial } \\
\text { vessels and basilar artery-normal }\end{array}$ & $\begin{array}{l}\text { ? Vascular (no medication } \\
\text { besides antihypertensive } \\
\text { drugs) }\end{array}$ \\
\hline 4 & $26 M$ & $\begin{array}{l}\text { For two weeks: horizontal diplopia } \\
\text { and dizziness; right internuclear } \\
\text { ophthalmoplegia. Spontaneous } \\
\text { course: } 12 \text { weeks later oculomotor } \\
\text { abnormalities and the hypertensive } \\
\text { lesions in the MRI were both gone }\end{array}$ & $\begin{array}{l}\text { Upbeat nystagmus syndrome } \\
\text { (Baclofen was given in the acute } \\
\text { phase for four weeks) }\end{array}$ & $\begin{array}{l}\text { MRI: hyperintense area of the } \\
\text { right midbrain tegmentum and the } \\
\text { anterior cerebellar vermis. CT, } \\
\text { EEG, evoked potentials, Doppler } \\
\text { ultrasonography, CSF-normal }\end{array}$ & $\begin{array}{l}\text { ?Most probably by an } \\
\text { inflammatory plaque }\end{array}$ \\
\hline 5 & $32 \mathrm{M}$ & $\begin{array}{l}\text { For two months: double vision, } \\
\text { postural instability, dizziness, } \\
\text { ataxia, which occurred three weeks } \\
\text { after enteritis. Progressive course }\end{array}$ & $\begin{array}{l}\text { Downbeat nystagmus syndrome } \\
\text { (progressive course) }\end{array}$ & $\begin{array}{l}\text { CSF: lymphocytic pleocytosis of } \\
144 / 3 \text { cells, normal proteins, MRI, } \\
\text { CT, cerebral angiography, evoked } \\
\text { potentials, para-neoplastic } \\
\text { screening methods-normal }\end{array}$ & ? Paraneoplastic \\
\hline 6 & $50 \mathrm{~F}$ & $\begin{array}{l}\text { For eight months: ovarian cancer } \\
\text { (stage } 3 \text { ), treated surgically and by } \\
\text { cytostatic drugs. Since two } \\
\text { months: acute cerebellar ataxia. } \\
\text { Cortisone therapy without clinical } \\
\text { improvement }\end{array}$ & Downbeat nystagmus syndrome & $\begin{array}{l}\text { CT, CSF, evoked potentials- } \\
\text { normal }\end{array}$ & $\begin{array}{l}\text { Paraneoplastic cerebellar } \\
\text { atrophy }\end{array}$ \\
\hline 7 & $30 \mathrm{~F}$ & $\begin{array}{l}\text { For several years spastic } \\
\text { paraparesis }\end{array}$ & $\begin{array}{l}\text { Slight downbeat nystagmus with } \\
\text { Frenzel's glasses, positional } \\
\text { downbeat nystagmus in head } \\
\text { hanging position }\end{array}$ & $\begin{array}{l}\text { MRI: a few small paraventricular } \\
\text { lesions; CSF, CT, evoked } \\
\text { potentials-normal }\end{array}$ & Multiple sclerosis \\
\hline 8 & $41 \mathrm{M}$ & $\begin{array}{l}\text { For } 15 \text { years: diabetes mellitus type } \\
\text { II, hypertension, eosinophile } \\
\text { granuloma of the lung. For a few } \\
\text { months: dizziness and instability of } \\
\text { the gait }\end{array}$ & $\begin{array}{l}\text { Slight downbeat nystagmus with } \\
\text { Frenzel's glasses, positional } \\
\text { downbeat nystagmus in head } \\
\text { hanging position }\end{array}$ & $\begin{array}{l}\text { CT, CSF, evoked potentials, } \\
\text { Doppler ultrasonography normal }\end{array}$ & $?$ \\
\hline 9 & $22 M$ & $\begin{array}{l}\text { For a few months archi- } \\
\text { neocerebellar ataxia, saccadic } \\
\text { smooth pursuit in the horizontal } \\
\text { and vertical plane }\end{array}$ & $\begin{array}{l}\text { Slight downbeat nystagmus with } \\
\text { Frenzel's glasses, positional } \\
\text { downbeat nystagmus in head } \\
\text { hanging position }\end{array}$ & $\begin{array}{l}\text { MRI, CSF: characteristic } \\
\text { abnormalities due to a multiple } \\
\text { sclerosis }\end{array}$ & Multiple sclerosis \\
\hline 10 & $31 \mathrm{M}$ & $\begin{array}{l}\text { For nine weeks: optic neuritis of } \\
\text { the right eye }\end{array}$ & $\begin{array}{l}\text { Slight downbeat nystagmus with } \\
\text { Frenzel's glasses, positional } \\
\text { downbeat nystagmus in head } \\
\text { hanging position }\end{array}$ & $\begin{array}{l}\text { MRI, CSF: characteristic } \\
\text { abnormalities due to a multiple } \\
\text { sclerosis }\end{array}$ & Multiple sclerosis \\
\hline
\end{tabular}

servo-controlled chair-drum system rotating about the vertical $\mathrm{Z}$-axis. A servo-controlled laser projection on a half-spherical screen (at a distance of $1.5 \mathrm{~m}$ ) provided the visual target for guided saccades. The test programme included measuring spontaneous nystagmus with the eyes closed and with the eyes open in the dark, fixation straight ahead, horizontal (up to $40^{\circ}$ ) and vertical (up to $20^{\circ}$ ) gaze. The vestibulo-ocular reflex (VOR) was tested by chair rotation in the light. For suppression of the VOR, the patient fixated on a small target light which moved together with the head. For quantitative evaluation of the suppression of the VOR (VOR-SUPP) the condition, when the patient was rotated in the light without fixating a target, was set 1 (no VOR suppression); a value of 0 was complete suppression of the horizontal VOR by visual fixation (perfect VOR suppression).

EOG recordings were performed before and on the third day of baclofen $(3 \times 5 \mathrm{mg})$ treatment (patients $1,2,3,4,5$ ) as well as before and four to five minutes after intravenous injection of $1 \mathrm{mg}$ physostigmine (patients $6,7,8,9,10$ ) or $2 \mathrm{mg}$ biperiden (patient 6 ).

\section{Results}

In all patients and conditions the mean slow phase velocity of the nystagmus was measured.

Baclofen treatment $3 \times 5 \mathrm{mg}$ (patients 1-5) (table 2)

Four patients (1-4) showed a suppression of 50 $(25-75) \%$ of the upbeat/downbeat nystagmus in the primary position of gaze and on lateral gaze or upward gaze (fig 1 ). In patient 2 , the beneficial baclofen effect could be reproduced after termination of the treatment for two days (fig 2). Patient 5 showed no beneficial effect under baclofen treatment (the increase in the slow phase velocity of the downbeat nystagmus can be explained by clinical progression of the disease).

\section{Physostigmine and biperiden injections (patient} 6) (table 3)

The downbeat nystagmus on fixation straight ahead $(9 \cdot 0 \mathrm{deg} / \mathrm{s})$ increased for $15-20$ minutes after injection of $1 \mathrm{mg}$ physostigmine (24.0 $\mathrm{deg} / \mathrm{s}$, fig 3). The gain for visual horizontal VOR suppression remained constant with 0.56 versus $0 \cdot 57$. 
Table 2 Upbeat and downbeat nystagmus in five patients before and during administration of $5 \mathrm{mg}$ baclofen three times daily. Slow phase velocity in

\begin{tabular}{|c|c|c|c|c|c|c|c|c|c|c|c|c|}
\hline \multirow{2}{*}{$\begin{array}{l}\text { SPV }(\% / s) \\
\text { Baclofen }\end{array}$} & \multicolumn{2}{|c|}{$\begin{array}{l}\text { Patient } 1(40, F) \\
\text { Upbeat } N\end{array}$} & \multicolumn{4}{|c|}{$\begin{array}{l}\text { Patient } 2(65, F) \\
\text { Downbeat } N\end{array}$} & \multicolumn{2}{|c|}{$\begin{array}{l}\text { Patient } 3(79, F) \\
\text { Downbeat } N\end{array}$} & \multicolumn{2}{|c|}{$\begin{array}{l}\text { Patient } 4(26, M) \\
\text { Upbeat } N\end{array}$} & \multicolumn{2}{|c|}{$\begin{array}{l}\text { Patient } 5(32, M) \\
\text { Downbeat } N\end{array}$} \\
\hline & No & Yes & No & Yes & No & Yes & No & Yes & No & Yes & No & Yes \\
\hline $\begin{array}{l}\text { SN down } \\
\text { FIX } 0^{\circ} \\
40^{\circ} \mathrm{R} \\
\mathrm{L} \\
20^{\circ} \mathrm{U} \\
\mathrm{D} \\
\text { VOR-SUPP }\end{array}$ & $\begin{array}{c}5-6 \\
19-21 \\
9-15 \\
26-27 \\
20-24 \\
10-11 \\
0 \cdot 29\end{array}$ & $\begin{array}{l}0 \\
5-7 \\
5-6 \\
12-18 \\
10-16 \\
3-4 \\
0 \cdot 23\end{array}$ & $\begin{array}{l}0 \\
4-8 \\
16-20 \\
10-12 \\
4 \\
0 \\
0 \cdot 36\end{array}$ & $\begin{array}{l}0 \\
0 \\
7-10 \\
2-3 \\
0 \\
0 \\
0 \cdot 33\end{array}$ & $\begin{array}{l}0 \\
4 \\
16-18 \\
8-9 \\
0 \\
0 \\
-\end{array}$ & $\begin{array}{l}0 \\
0 \\
9-10 \\
5-6 \\
0 \\
0 \\
-\end{array}$ & $\begin{array}{l}4 \\
0 \\
8-10 \\
10-12 \\
4 \\
4 \\
0 \cdot 12\end{array}$ & $\begin{array}{l}0 \\
0 \\
2-4 \\
6-8 \\
0 \\
0 \\
0 \cdot 14\end{array}$ & $\begin{array}{l}0 \\
3-8 \\
3-5 \\
0 \\
3 \cdot 5-6 \cdot 5 \\
2-3 \\
-\end{array}$ & $\begin{array}{l}0 \\
1 \cdot 5-2 \\
0 \\
0 \\
1 \cdot 5-3 \cdot 5 \\
0 \\
-\end{array}$ & $\begin{array}{l}12-18 \\
12-18 \\
12-14 \\
13-16 \\
5-6 \\
10-15 \\
-\end{array}$ & $\begin{array}{r}18-21 \\
18-21 \\
18-21 \\
19-22 \\
9-12 \\
17-19 \\
-\end{array}$ \\
\hline
\end{tabular}

$\mathrm{SN}=$ spontaneous nystagmus with eyes closed; FIX $0^{\circ}=$ fixation straight ahead; $40^{\circ} \mathrm{R} / \mathrm{L}=$ gaze $40^{\circ}$ right $/$ left; $20^{\circ} \mathrm{U} / \mathrm{D}=$ gaze $20^{\circ}$ up $/$ down; VORSUPP $=$ suppression of horizontal vestibulo-ocular reflex by visual fixation.

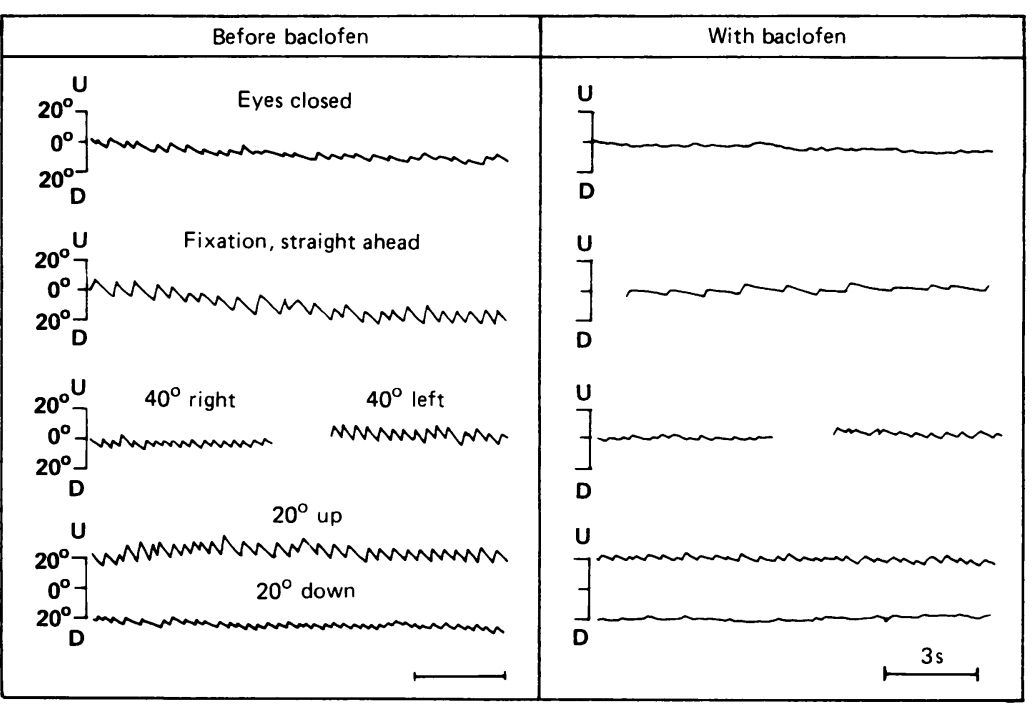

Figure 1 EOG-recordings of vertical eye-movements in a patient (1) with upbeat nystagmus due to a metastasis of the right ponto-medullary brainstem. Considerable suppression of upbeat nystagmus ( $57 \%$ reduction in slow phase velocity) by oral treatment with baclofen, $5 \mathrm{mg}$ three times daily.

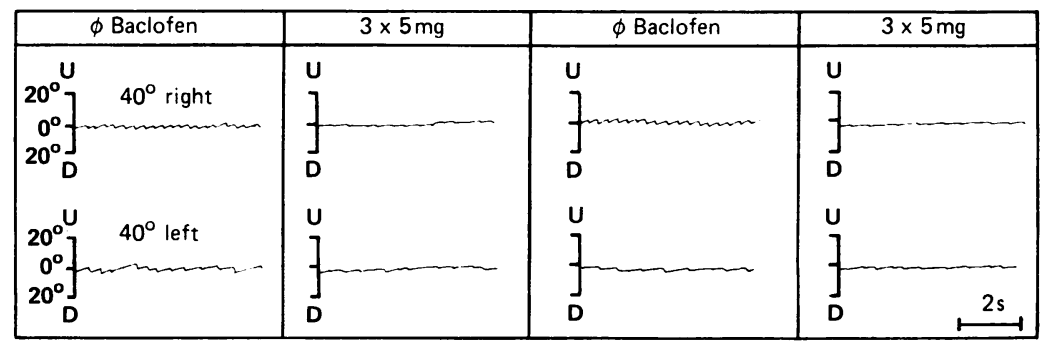

Figure 2 EOG-recordings of vertical eye-movements in a patient (2) with downbeat nystagmus from multiple sclerosis. The recordings were taken with gaze either $40^{\circ}$ right or left to activate downbeat nystagmus. Note the beneficial effect of baclofen given $5 \mathrm{mg}$ three times daily (left), as well as the reoccurrence of the nystagmus after two days without drug therapy. The nystagmus responded to a second course of treatment (right).

Table 3 Downbeat nystagmus (patient 6). Mean and standard deviation of the slow phase velocity $(S P V$ in $\% s$ ) of the downbeating nystagmus before drug administration, after intravenous injection of $1 \mathrm{mg}$ physostigmine (cholinergic drug) and after $a$ subsequent injection of $2 \mathrm{mg}$ Biperiden (anticholinergic drug)

\begin{tabular}{|c|c|c|c|}
\hline$S P V(\% / s)$ & Before drugs & Physostigmine $1 \mathrm{mg}$ iv & Biperiden $2 \mathrm{mg}$ iv \\
\hline $\begin{array}{l}\text { SN down } \\
\text { FIX } 0^{\circ} \\
40^{\circ} \mathrm{R} \\
\quad \mathrm{L} \\
\text { VOR-SUPP }\end{array}$ & $\begin{array}{l}5.5(2 \cdot 0) \\
9 \cdot 0(2 \cdot 5) \\
8.5(2.0) \\
8.5(2.5) \\
0.56\end{array}$ & $\begin{array}{l}15 \cdot 0(3 \cdot 0) \\
24 \cdot 0(3 \cdot 0) \\
53 \cdot 0(10 \cdot 0) \\
53 \cdot 0(11 \cdot 0) \\
0.57\end{array}$ & $\begin{array}{l}14.0(3.0) \\
10.0(2.0) \\
- \\
0.56\end{array}$ \\
\hline
\end{tabular}

$\mathrm{SN}=$ spontaneous nystagmus with eyes closed; FIX $0^{\circ}=$ fixation straight ahead; $40^{\circ} \mathrm{R}$ $\mathrm{L}=$ gaze $40^{\circ}$ right $/$ left; VOR-SUPP $=$ suppression of horizontal vestibulo-ocular reflex by visual fixation.
Biperiden injection $(2 \mathrm{mg}$; anticholinergic drug), 10 minutes after physostigmine injection, diminished the enhanced downbeat nystagmus during fixation straight ahead from 24 to $10 \mathrm{deg} / \mathrm{s}$, whereas the nystagmus with eyes closed was not significantly changed $(15 \mathrm{deg} / \mathrm{s}$ versus $14 \mathrm{deg} / \mathrm{s}$ ). The gain of visual horizontal VOR suppression was unchanged $(0 \cdot 56)$.

Physostigmine injection $1 \mathrm{mg}$ (patients 7-10) (table 4)

All four patients with positional downbeat nystagmus were recorded with their heads in the upright position. They all showed an increased downbeat nystagmus with the eyes closed (for 15-20 minutes, four to five minutes after the intravenous injection of $1 \mathrm{mg}$ physostigmine; table 4).

\section{Controls}

After physostigmine injection, the two control subjects did not show any eye movement disorder.

\section{Discussion}

This study was stimulated by earlier reports on the efficacy of baclofen for symptomatic treatment of periodic alternating nystagmus. ${ }^{16}$ In our study, a beneficial effect of baclofen was observed in two patients with upbeat nystagmus and two patients with downbeat nystagmus. One patient with downbeat nystagmus did not respond to baclofen. The four patients described here experienced a considerable reduction in oscillopsia amplitude as long as baclofen was given (low dose of $3 \times 5 \mathrm{mg}$ daily, observation time: two to four weeks). No adverse effects were reported. Five other patients with downbeat (1) or positional downbeat nystagmus (4) showed a distressing transient (15-20 minutes) increase of nystagmus velocity following intravenous injection of $1 \mathrm{mg}$ physostigmine.

Both effects, reduction and augmentation of ocular oscillation, could be explained by the different interactions of baclofen and physostigmine on neurotransmission subserving vertical VOR.

Enhancement of acquired downbeat nystagmus by physostigmine, a cholinergic effect?

Cholinergic pathways are known to convey the visual input to the vestibulo-cerebellum (flocculus, nodulus, ventral uvula, ventral parafloc- 


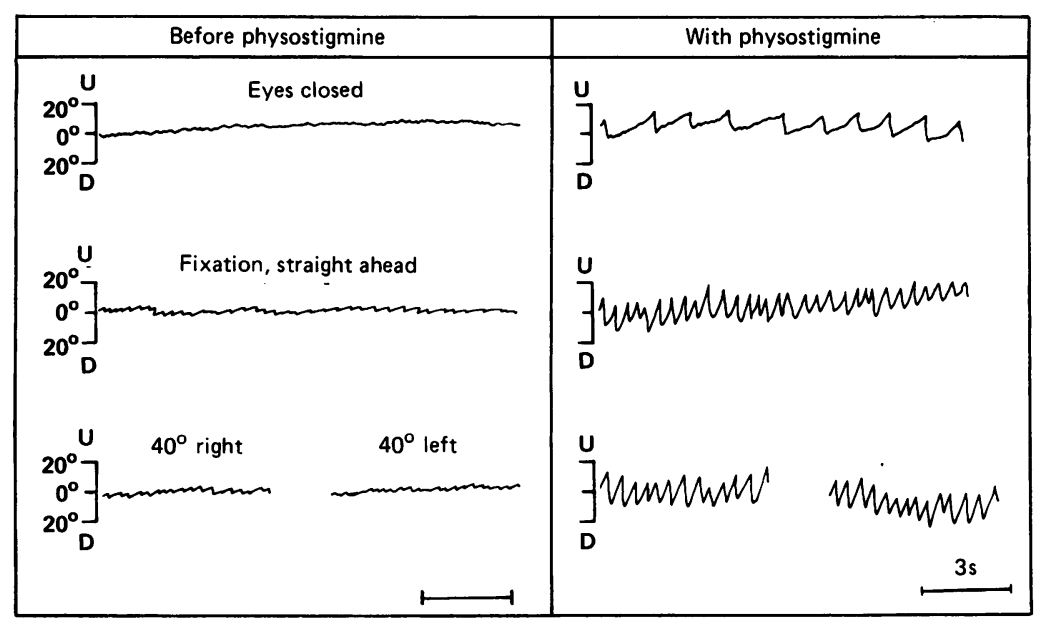

Figure 3 EOG-recordings of vertical eye-movements in a patient (6) with downbeat nystagmus in paraneoplastic cerebellar syndrome. The downbeat nystagmus (SPV 9.0 deg/s, fixation straight ahead) increases both in amplitude and slow phase velocity (SPV 24.0 deg/s) for 15-20 minutes after intravenous injection of $1 \mathrm{mg}$ physostigmine.

Table 4 Positional downbeat nystagmus (patients 7-10). Slow phase velocity (SPV in $\%$ ) of the downbeating nystagmus with eyes closed before and after a single intravenous injection of $1 \mathrm{mg}$ physostigmine

\begin{tabular}{|c|c|c|c|c|}
\hline $\begin{array}{l}\text { Physostigmine } 1 \mathrm{mg} \text { iv } \\
\operatorname{SPV}\left({ }^{\circ} / \mathrm{s}\right)\end{array}$ & $\begin{array}{l}7 \\
(30, F)\end{array}$ & 8 & $\begin{array}{l}9 \\
(22, M)\end{array}$ & $\begin{array}{l}10 \\
(31, M)\end{array}$ \\
\hline $\begin{array}{l}\text { Before } \\
\text { SN hori } \\
\text { SN vert }\end{array}$ & $\begin{array}{l}2.0 \mathrm{r} \\
5.0 \mathrm{~d}\end{array}$ & $\begin{array}{l}2.0 \mathrm{r} \\
3.5 \mathrm{~d}\end{array}$ & $\begin{array}{l}2 \cdot 0 \mathrm{r} \\
2 \cdot 0 \mathrm{~d}\end{array}$ & $\begin{array}{l}2.0 \mathrm{r} \\
2.0 \mathrm{~d}\end{array}$ \\
\hline $\begin{array}{l}\text { After } \\
\text { SN hori } \\
\text { SN vert }\end{array}$ & $\begin{array}{r}2.0 \mathrm{r} \\
10.0 \mathrm{~d}\end{array}$ & $\begin{array}{l}0 \\
7 \cdot 0 \mathrm{~d}\end{array}$ & $\begin{array}{l}2.01 \\
8.0 \mathrm{~d}\end{array}$ & $\begin{array}{l}2.0 \mathrm{r} \\
6.0 \mathrm{~d}\end{array}$ \\
\hline $\begin{array}{l}\text { Before VOR-SUPP } \\
\text { After VOR-SUPP }\end{array}$ & $\begin{array}{l}0.63 \\
0.54\end{array}$ & $\begin{array}{l}0 \\
0\end{array}$ & - & $\begin{array}{l}0 \\
0\end{array}$ \\
\hline
\end{tabular}

$\mathrm{SN}=$ spontaneous nystagmus with eyes closed and head upright; hori = horizontal componen $\mathrm{SN}=$ spontaneous nystagmus with eyes closed and head upright; hori $=$ horizontal component
of the downbeating nystagmus; vert = vertical component down; $\mathrm{r}=$ right; $1=$ left; $\mathrm{d}=$ down;

of the downbeating nystagmus; vert $=$ vertical component down; $\mathrm{r}=$ right; $1=$ lef
VOR-SUPP $=$ suppression of horizontal vestibulo-ocular reflex by visual fixation.

culus). ${ }^{21}$ The vestibulo-cerebellum modulates the VOR gain by inhibitory Purkinje cell output. Afferent visual signals can reach the flocculus by two different pathways: 1) mainly via the accessory optic tract and pretectal nuclei to the dorsal cap of the inferior olive, which represents the final relay for the visual climbing fibre system with high cholinergic activity; ${ }^{1522-25}$ 2) via the mossy fibre projections, which also have cholinergic input. ${ }^{26}$ The climbing fibre system is involved in the adjustment of the VOR. $^{27}$

The results of pharmacological studies, however, cannot be simply explained by cholinergic or anticholinergic effects. Thurston et $a l^{16}$ showed that physostigmine reduced a hyperactive VOR gain (measured in the dark) in a patient with a cerebellar degeneration, whereas neither baclofen nor diazepam were able to modulate VOR gain in this case. One might speculate that cholinergic intensification of the visual input in this particular patient caused the reduction of the hyperactive VOR by long term adaptation. In contrast to this observation, we saw a transient increase of nystagmus amplitude in our downbeat and positional downbeat nystagmus patients following physostigmine application. Nicotine, a cholinergic agent, is probably responsible for the tobacco-induced primary position upbeat nystagmus in normal subjects, ${ }^{28-31}$ which may also be explained as a central vestibular tone imbalance rather than an effect on the visual pursuit system. This explanation is consistent with the findings by Sibony et al $^{29}{ }^{30}$ on horizontal and vertical eye movements in smoking in normal subjects.

There are two possible explanations for the enhancement of downbeat nystagmus by physostigmine injection in our cases. Firstly, a directional imbalance of the vertical VOR causes downbeating nystagmus. A simultaneous increase in the up and down tone by physostigmine induces an absolutely greater tone imbalance between both directions which subsequently enhances downbeat nystagmus. In contrast, there was no pre-existing tone imbalance in the patient with hyperactive VOR described by Thurston et al. ${ }^{16}$ In this case therefore physostigmine could not enhance imbalance but reduced hyperactive VORresponse.

Secondly, there is an inadequate visual input in the hyperactive VOR by the climbing fibre system. It is predicted that physostigmine can improve this input and reduce the VOR gain consistent with the patient described by Thurston et al. ${ }^{16}$ In patients with downbeat nystagmus of different origins, however, there might be different capacities to use the visual signal so that only some of the patients have an improvement of downbeat nystagmus by fixation. ${ }^{32}$ It can be speculated that in some cases physostigmine improves visual fixation. In other cases, there might be no effect on the slow phase of the downbeat nystagmus or a worsening of the visual fixation causing an increase in slow phase velocity.

Reduction of upbeat/downbeat nystagmus, $a$ $G A B A-B$-ergic-, or a anti-glutaminergic effect? The inhibitory Purkinje cell output from the vestibulo-cerebellum uses GABA as an inhibitory transmitter. ${ }^{33}$ Aspartate and glutamate are excitatory transmitters of the cerebellar cortex. ${ }^{27}$

Baclofen is an effective drug in reducing the periodic alternating nystagmus that occurs after cerebellar or posterior fossa lesions ${ }^{18}$ or after nodulus and uvula ablation. ${ }^{34}$ It also appears likely that baclofen, a GABA-B-agonist, augments the physiological inhibitory influence of the vestibulo-cerebellum on the vestibular nuclei in our cases of upbeat and downbeat nystagmus. A GABA antagonist should therefore result in the opposite, a disinhibition with increased nystagmus. The only study in humans ${ }^{35}$ dealing with the influence of a GABA antagonist (picrotoxin) is related to the effect on peripheral vestibular function (distinct suppression of spontaneous nystagmus, vertigo, caloric excitability of the labyrinths). Its effect on the central pathways are less conclusive: a latent central spontaneous nystagmus became manifest, and a manifest central spontaneous nystagmus remained unchanged. ${ }^{35}$ In monkeys, Gavin and Blair ${ }^{36}$ found that picrotoxin was able to decrease the nystagmus time constant and the nystagmus asymmetry. It also antagonised diazepam in 
increasing the time constant of the vestibular nystagmus. In addition to the fast build up of compensatory eye movements during optokinetic stimulation, there is another process with a slow build up of the slow phase velocity mediated by the "velocity storage mechanism" 37 which causes a prolongation of the vestibular time constant. The velocity storage is also utilised in mediating interactions between the visual and vestibular system, ${ }^{38} 39$ the vertical and horizontal semicircular canals $^{4041}$ and between the otoliths and the semicircular canals. ${ }^{4243}$ Cohen et al $^{37}$ could show an effect of baclofen on the VOR that could be modelled as an alteration in the time constant of the velocity-storage mechanism. Based on these results, it seems likely that the GABA-B agonist baclofen acts with an inhibitory control on the velocity storage.

There is a second explanation which seems less likely. Glutamate/aspartate have been proposed as excitatory neurotransmitters of the granule cells which then contact the dendrites of the Purkinje cells via excitatory parallel fibres. ${ }^{274}$ Baclofen antagonises - excitatory transmission, possibly by presynaptic depressing the release of glutamate and aspartate..$^{45}$ Its beneficial effect on distressing upbeat and downbeat nystagmus might therefore be due to an anti-glutaminergic action on cerebellar cortex. This explanation is contradicted by the experimental observation in monkeys that the narcotic glutamate antagonist ketanest may elicit transient upbeat nystagmus (unpublished personal observation).

As baclofen seems to be a useful drug for treatment of periodic alternating nystagmus and upbeat and downbeat nystagmus, this might imply a common neurochemical mechanism. The manifestations of the different ocular motor disorders are then due to the site of the lesion. Some questions remain unanswered, such as, why are all of the patients with upbeat and downbeat nystagmus not responsive to baclofen therapy? Are these differential effects due to different sites of the lesion?

How can the contradictory effects of GABAantagonists and glutamate antagonists be interpreted in the literature?

Finally, what is the long term efficiency of baclofen on upbeat and downbeat nystagmus?

Nevertheless, our results offer a new possibility of medical treatment for some patients with upbeat and downbeat nystagmus. Baclofen treatment should be tried in these patients. A prospective double blind study is essential to answer some of these questions.

This work was supported by Deutsche Forschungsgemeinschaft (SFB 220) and Wilhelm-Sander-Stiftung.

1 Baloh RW, Spooner JW. Downbeat nystagmus. A type of central vestibular nystagmus. Neurology $(N Y)$ 1981; 31:304-10.

2 Büchele W, Brandt TH, Degner D. Ataxia and oscillopsia in downbeat nystagmus/vertigo syndrome. Advances of OtoRhino-Laryngology 1983;30:291-7.

3 Gresty M, Baratt H, Rudge P, Page N. Analysis of downbeat nystagmus. Otolithic versus semicircular canal influences.
Arch Neurol 1986;43:52-5.

4 Zee DS, Friendlich AR, Robinson DA. The mechanism of downbeat nystagmus. Arch Neurol 1974;30:227-37.

5 Büttner-Ennever JA. Vestibular-oculomotor organization. In: Fuchs AF, Becker W, eds. Progress in oculomotor research. North-Holland: Elsevier, 1981:361-70.

6 Blanks RHJ. Cerebellum. In: Büttner-Ennever JA, ed. Neuroanatomy of the oculomotor system. Amsterdam: Elsevier, 1988:225-72.

7 Benjamin EE, Zimmermann CF, Troost BT. Lateropulsion and upbeat nystagmus are manifestations of central vestibular dysfunction. Arch Neurol 1986;43:962-4.

8 Keane JR, Itabashi HH. Upbeat nystagmus: clinicopathologic study of two patients. Neurology 1987;37: 491-4.

9 Nakada T, Remler MP. Primary position upbeat nystagmus. Journal of Clinical Neuroophthalmology 1981;1:185-9.

10 Ranalli PJ, Sharpe JA. Upbeat nystagmus and the ventral tegmental pathway of the upward vestibulo-ocular reflex. Neurology 1988;38:1329-30.

11 De Jong JMBV, Cohen B, Matsuo V, Uemura T. Midsagittal ponto-medullary brain stem section: Effects on ocular adduction and nystagmus. Experi Neurol 1980;68:420-2.

12 Takemori T, Suzuki M. Cerebellar contribution to oculomotor function. Oto-Rhino-Laryngology 1977;39: 209-17.

13 Zee DS, Yamazaki A, Butler PH, Gücer F. Effects of ablation of flocculus and paraflocculus on eye movements in primate. J Neurophysiol 1981;46:878-99.

14 Kark RAP, Blass JP, Spence MA. Physostigmine in familial ataxias. Neurology 1977;27:70-2.

15 Tijssen CC, Endtz LJ, Goor C. The influence of physostigmine on visual-vestibular interaction in hereditary
ataxias. $J$ Neurol Neurosurg Psychiatry 1985;48:977-81.

16 Thurston SE, Leigh JR, Abel LA, Dell'Osso L. Hyperactive vestibulo-ocular reflex in cerebellar degeneration: Pathovestibulo-ocular reflex in cerebellar degeneratio

17 Jabbari B, Rosenberg M, Scherokman B . Effectiveness of trihexyphenidyl against pendular nystagmus and palatal myoclonus: Evidence of cholinergic dysfunction. Movement Disorders 1987;2:93-8.

18 Halmagyi GM, Rudge P, Gresty MA, Leigh RJ, Zee DS. Treatment of periodic alternating nystagmus. Ann Neurol 1980;8:609-11.

19 Carlow TJ. Medical treatment of nystagmus and ocular motor disorders. Int Ophthalmol Clin 1986;26(4):251-64.

20 Nuti D, Ciacci G, Giannini F. Aperiodic alternating nystagmus: Report of two cases and treatment by baclofen. Italian Journal of Neurological Science 1986;7:453-9.

21 Leigh RJ, Zee DS. The neurology of the eye movement. Contemporary Neurology Series, Vol 23. Philadelphia: F A Davies Company, 1983

22 Maekawa K, Takeda T. Electrophysiological identification of the climbing and mossy fiber pathways from the rabbit's retina to the contralateral cerebellar flocculus. Brain Res 1976;109:168-74

23 Marani E, Voogd J, Boekee A. Acetylcholinesterase staining in subdivisions of the cat's inferior olive. J Comp Neurol 1977;174:209-26

24 Rotter A, Birdsall NJM, Burgen ASV. Muscarinic receptors in the central nervous system of the rat. I. Technique for autoradio-graphic localisation of the binding of $(3 \mathrm{H})$ propylbenzylcholine mustard and its distribution in the forebrain. Brain Res Rev 1979;1:141-65.

25 Rotter A, Birdsall NJM, Field PM, Raisman G. Muscarinic receptors in the central nervous system of the rat. II. Distribution of binding of $(3 \mathrm{H})$ propylbenzylcholine mustard in the midbrain and hindbrain. Brain Res Rev 1979;1:167-83.

26 Kan KSK, Chao LP, Eng LF. Immunohistochemical localisation of choline acetyltransferase in rabbit spinal cord and cerebellum. Brain Res 1978;146:221-9.

27 Ito $M$. Glutamate as a neurotransmitter in the cerebellar cortex. Biomed Res 1984;5(suppl):63-6.

28 Neveling R, Kruse KE. UUber Nikotinnystagmus Archiv Ohren-Heilkunde und Zeitschrift für Hals-Heilkunde 1961;177:427-31.

29 Sibony PA, Evinger C, Manning KA. Tobacco-induced primary-position upbeat nystagmus. Ann Neurol 1987;21:53-8.

30 Sibony PA, Evinger C, Manning KA. The effects of tobacco smoking on smooth pursuit eye movements. Ann Neurol 1988;23:238-41.

31 Leigh RJ. Brainstem control of vertical gaze. In: Kennard C, Clifford Rose F, eds. Physiological aspects of clinical neuroophthalmology. London: Chapman and Hall 1988:237-48.

32 Crevits L, Reynaert C. Downbeat nystagmus. An electrooculographic study. Neuroophthalmology 1989;9:43-8.

oculographic study. Neuroophthalmology $1989 ; 9: 43-8$.
33 Precht W, Baker R, Okada Y. Evidence of GABA as the synaptic transmitter of the inhibitory vestibulo-ocular synaptic transmitter of the inhibitory vestit

34 Waespe W, Cohen B, Raphan T. Dynamic modification of the vestibulo-ocular reflex by the nodulus and uvula. the vestibulo-ocular reflex
Science 1985;228:199-202.

35 Ehrenberger K, Benkoe E, Felix D. Suppressive action of picrotoxin, a GABA antagonist, on labyrinthine spontaneous nystagmus and vertigo in man. Acta Otolaryngologica 1982;93:269-73.

36 Gavin M, Blair S. Modification of the macaque's vestibuloocular reflex by picrotoxin. Arch Otolaryngology 1981;107:372-6.

37 Cohen B, Helwig D, Raphan T. Baclofen velocity storage: A model of the effect of the drug on the vestibular ocular reflex on the rhesus monkey. J Physiol 1987;393:703-25. 
38 Waespe C, Henn V. Neuronal activity and the vestibular nuclei of the alert monkey during vestibular and optokinetic stimulation. Exper Brain Res 1977;27:523-38.

39 Raphan T Matsuo V, Cohen B. Velocity storage in the vestibular ocular reflex arc (VOR). Exper Brain Res 1979;35:229-48.

40 Raphan T, Cohen B, Henn V. Effects of gravity on rotatory nystagmus in monkeys. Ann NY Acad Sci 1981;374: nystagmus in monkeys. Ann NY Acad Sci 1981;374:

41 Raphan

Raphan T, Cohen B, Suzuki JI, Henn V. Nystagmus
generated by sinusoidal pitch while rotating. Brain Res 6:165-72.

42 Cohen B, Suzuki JI, Raphan T. Role of the otolith organs in generation of horizontal nystagmus: Effects of selective labyrinthine lesions. Brain Res 1983;276:159-64.

43 Raphan T, Cohen B. Velocity storage and the ocular response to multidimensional vestibular stimuli. In: Berthoz A, Melvill Jones G, eds. Adaptive mechanism in gaze control: facts and theories. Amsterdam: Elsevier North Holland Press, 1985:123-43.

44 Ross CA, Bredt D, Snyder SH. Messenger molecules in the cerebellum. TINS 1990;13(6):216-22.

45 Johnston GAR, Hailston MH, Freeman CG. Baclofen: stereo-selective inhibition of excitant amino acid release. $J$ Pharmaceut Pharmacol 1981;32:230-1.

46 Olpe HR, Baudry M, Fagni L, Lynch G. The blocking action of baclofen on excitatory transmission in the rat hippocampal slice. J Neurosci 1982;2:698-703. 